\title{
Intermediate Osteoclastic Giant Cell-Rich Tumor of Bone
}

National Cancer Institute

\section{Source}

National Cancer Institute. Intermediate Osteoclastic Giant Cell-Rich Tumor of Bone. NCI

Thesaurus. Code C121931.

A benign but locally aggressive giant cell tumor that arises from the bone. 